\title{
Implementation of U.S. Immigration Policies
}

\author{
Burçak Gündal
}

Sıddıka Öztekin

\begin{abstract}
Immigration and refugees are sets of global flows of people who are seeking information, technology, economic stability, and military, political, and social asylum. Immigrants and refugees, which is one of the categories of migrants, represent only one of many global exchanges in an increasingly independent world. As the number of immigrants increases, the national, demographic, and socio-economic composition of the foreign residents in a host country are impacted by the immigration and immigrant policies of the receiving country. Immigration is inseparably part of the American national identity and always will be, and the United States would not continue to grow without immigration. In setting immigration policy in the United States, policymakers must be sensitive to both the U.S. vulnerabilities and the effects of American policies on the countries of origin. Since the post 9/11 period in the United States, immigration, immigration policy and implementation have been debated issues. Especially after Donald Trump was elected, the debate about migrants and immigration issues has increased even more. The purpose of this study is to show the development of immigration in American history, the positive and negative effects of immigrants on American economy and social life, and the question of the effects of social inclusion policies on the immigrant problem.
\end{abstract}

Keywords: Immigration, The effects of immigrants, The United States' immigration policy, social inclusion.

\section{Introduction}

The decision of immigration consists of two characteristics, which are "push" migrants away from their home and "pull" migrants toward the receiving area. These differentials may be economical, such as differences in earnings, employment, and educational opportunities, or political, such as differences in freedoms rights or family, such as differences in the geographic location of family members (Immigration Policy Institute, 2015). The policy issues that result are different and complicated to solve also, immigration policy issues differ from country to country, according to their demands, values, and needs (Hochschild \&Mollenkof, 2008, p.3).

In 2010, there were 40 million foreign-born people living the United States, and 220 million international migrants in the world. Almost one in five residents in the United States was immigrants. Therefore, the U.S. is known as the heart of immigration, or as a "nation of immigrants" (Hirschman, 2006, p.1) After the terrorist attacks of September 11, 2001, American policymakers decided that the immigration system required a thorough critical reexamination and potential overhaul in order to prevent future attacks (Siavelis \& Coates, 2009, p.50). Since the post 9/11 period in the United States, immigration, immigration policy and implementation have been debated issues (Brick, Challinor \& Rosenblum, 2011, p.1). Also the question of immigration from Mexico, and other Latin Americans became more noticeable. According to Barrack Obama's report in 2014, the old administrative weakness had to be lifted and new reforms had to be settled in the solution of the immigration problem. These innovations needed to be regulated in a way that would include the rights of migrants, illegal immigrants and their families, and in the visa system to meet the needs of the day. Innovations in migration management had to be included in the implementation area of regulations and integrated within social and economic changes within the security axis of border management (American Immigration Council). However, Donald Trump's exclusive and polarizing discourse for immigrants in the 2016 elections contrasts with the immigrant country of the United States.

Immigration provides the United States with new ideas, allowing innovation, the U.S. to become a more productive, competitive, and successful nation in the 21st century. In the United States, the group size of immigrants, the historical legacy of immigration, and the recent immigration growth rate all vary by locale and region (Gold \& Rumbaut, 2009). 
However, although immigrants bring benefits that improve American culture, both immigrants and U.S. citizens also construct many barriers, such as illegal immigration and unauthorized immigrants in the United States. Politicians must consider how immigration policy will affect sending and receiving countries' residents' recent and future demands. The policy mechanism should support an evaluation of current immigration policy and new immigration policy should be established (Immigration Policy Institute, 2015).

\section{Positive effects of Immigration}

Migration has both positive and negative sides for the communities to which they migrate. Positive impacts happen if migrants volunteer, and are allowed to improve their new communities' economic, social, and cultural opportunities. Therefore, migrants are not only winners but sometimes also losers in the immigration process (Martin\& Hamutal, 2011, p.50). The US is the country that receives the most immigration in the World. Migrants in the United States are more assimilated compared to European countries, and migration policy in the United States is a controversial topic. While discussions are usually interested in cultural issues, immigration has economic implications. Economic research finds little evidence that foreign labor reduces US wages and jobs. Estimates of economic theories and academic research indicate that immigration does not affect long-term wages and has a positive impact on migration for the domestic and general economy (www.budgetmodel.wharton.upenn.edu). Immigration has a positive effect on the country of origin. Immigrants improve the receiving countries' trade balance, and reduce unemployment and higher wages. However, immigration generates more costs than benefits for the nation, resulting in a major public policy issues (Asch, 1994, p.193-198).

Research confirms that the legalization of migration and the increase of legal immigration will increase the economy and increase tax revenues. The results of the survey show that GDP will increase, enactment will have more tax revenue, and immigrants will have more economic activity and will pay more taxes. GDP gains vary from 0.3 per cent to 0.8 per cent ( 83 billion to 150 billion dollars), depending on the increase in labor power through immigration reform and the increase in the income of illegal immigrants to be enacted (Enchautegui, Lindner, Poethig, 2013, p.12). In the last decade, $43 \%$ of the increase in the labor force in the United States constitutes immigrants. Immigrants represented about a quarter of entries into the most strongly declining occupations in United States (28\%). These jobs include in the United States, they concern mostly jobs in production, installation, maintenance and repair (www.oecd.org).

Immigration has an important effect on the size and distribution of the United States. Most immigrants come to the United State because of its economic opportunities. Many immigrants have become naturalized U.S. citizens and vote, and some hold political office. Because the United States provides economic opportunities and social benefits, hundreds of millions more people would immigrate to the United States. Immigration has been encouraged by economic transformation, helping the United States adjust to new economic conditions. Immigration can be an essential and effective tool for the United States' foreign policy, which helps the U.S. gain political influence overseas. (Meissner, Meyers, Papademetriou, \&Fix, 2006, p.51). Undocumented immigrants provide substantial support to the social security system. Each year, Social Security taxes are withheld from billions of dollars in wages earned by workers whose names and Social Security numbers do not match the records of the Social Security Administration (SSA). According to records of social security administrations illegal immigrants paid \$ 13 billion payroll taxes to Social Security Foundation Funds in 2010 (Stephen Goss, et al, 2013, p. 3).

Immigrants create significant employment in large and small businesses. A report from the Fiscal Policy Institute found that immigrant-owned small businesses employed 4.7 million people and had $\$ 776$ billion in receipts in 2007 . With it 18 percent of business owners in the U.S. were foreign-born -higher than the immigrant share of the population (13 percent) or labor force (16 percent) (Kallick, 2015, p.2.). Therefore, the United States must be selective in its immigration policy. Immigration policy should be designed to assist immigrants' contribution to the economy (Fargues, Demetrios, Papademtriou, Giambattista, \& Madeleine, 2011, p. 7-27). Current immigration policies with respect to both legal and illegal immigration encourage the entry of a disproportionate number of poor immigrants into the United States. The U.S. immigration policy should help U.S. citizens achieve the American dream. Americans should determine U.S. immigration policy and benefits (Siavelis \& Coates, 2009, pg. 32). Immigrants and refugees become a fundamental part of the local communities, economies, and labor markets of America, affecting a growing population and the history of immigration (Fargues, Demetrios, Papademtriou, Giambattista, \& Madeleine, 2011, p.5-14).

Building relationships between refugee and immigrant organizations and receiving communities fosters two-way integration (Office of Refugee Resettlement). Immigrants assist the United States in being a leader of the competitive international market, and in creating new jobs regarding changing global market conditions (Office of Refugee Resettlement). Immigrant 
workers are raising the sorrows of domestic workers in two ways. First, the level of education of immigrants and local workers and the professions and skills they are working in are different. Along with this, the work done by domestic and migrant workers is linked. So increasing the productivity of these domestic workers raises their wages. Second, the addition of immigrant workers to the labor force stimulates new investment in the economy, which in turn increases the demand for labor, exerting upward pressure on wages. (Peri, 2006; p. 6,)

\section{Negative effects of Immigration}

Most Americans are beginning to acknowledge the positive effects of immigrants. On the other hand, many Americans fear that the United States has too many immigrants. Most immigrants are assimilated by American economy, society, and culture. The United States is known as a nation of immigrants, but most Americans want immigration restricted in spite of this (Gold \& Rumbaut, 2009). However, many immigrants, older generations of them, refuse to join the American mainstream, and are not assimilated into American society. The first generation settles in ethnic regions, maintains culture continuity with their origins, and prefers to speak their mother tongue. The second generation speaks fluent English and is eager to join the American mainstream. However, this assimilation is not painless, automatic, and immediate (Hirschman, 2006, p. 5-6). For Instance, new immigrants face more extensive obstacles than second- generation immigrants, regarding political participation, the low level of education and English proficiency, and their undocumented or illegal immigrants as well as legal immigrants. On the other hand, second-generation Mexican and Central American immigrants have a force to shape future political life in the United States, because of their English abilities, highly skilled workforce, and their citizenship status. Therefore these immigrants from Mexico and Central America play key roles in the economic, social, and political life of the United States (Brick, Challinor \& Rosenblum, 2011, p.7-16).

Immigration has had a disproportionate effect on the demographic size, ethnic diversity, culture, and character of American society. Immigrants and their children are assimilated and adapt to American society, and immigrants participate in American institutions in ways that are allowed in American culture (Hirschman, 2014, p. 7-9). The political struggle results from the concern that high levels of immigration might create problems more difficult to solve than the typical economic, cultural, and security problems. The immigration problem is a prior policy problem; governments should implement immigration policy that involves immigrants in the policy decision-making process (Hochschild \&Mollenkof, 2008, pg.3-5).

Because immigrants move into areas that tend to be more disorganized, and face many economic, cultural, and social barriers, the United States has a high level of crime rate among immigrants and their living areas (Mears, 2002, pg. 284288)

Displaced people and unauthorized immigrants encounter significant risks; giving the impression that migration is out of control. The common belief is that immigrants displace existing workers and reduce their wages, as well as threating the nations' cultural identity (Fargues, Demetrios, Papademtriou, Giambattista, \& Madeleine, 2011, pg.5).

Illegal immigration produces insecurity about America's borders, economy, and costs of an isolated underclass. Illegal immigration has also impact on wages at the bottom of the pay scale.

Unauthorized immigrants cannot be integrated into American society. Because of the high cost of unauthorized immigrants, communities face the problem of demands for services from unauthorized immigrants, such as education and health care.

Illegal immigration has a dramatic effect on the United States. Immigration policy has mainly been a part of federal responsibilities. Because illegal immigration is a regional matter, debate of the United States immigration policy is overwhelmingly a domestic issue. At the national level, migration is not an influential tool to solve unemployment. The effect of immigration on the unemployment rate is that immigration is a regional problem. For instance, in 2013, the top six states with the largest proportion of Mexican immigrants were California, which is the 37 percent of the total Mexican immigrant population, Texas, which is the 22 percent of total Mexican immigrants, Illinois, which is the 6 percent, Arizona is the 4 percent, and Georgia is 2 percent as well as Florida' Mexican immigrants populations (DHS, 2014). These effects can be problematic to determine at the national level. The economic effect of immigration on the sending countries is an increase in unemployment in the receiving country (Asch, 1994, p.185-205). Local communities also face problems of health care and education facilities. Local policy programs create or enhance education systems, help reduce income inequality, and support small businesses and establishments (Meissner, Meyers, Papademetriou, \&Fix, 2006, p.100). 
The problems of employment are language proficiency, level of education, discrimination, foreign qualifications, and access to social and professional networks. These problems impact on policymakers to consider their views of immigrants concerning the academic performance of migrants' youth, low employment rates, dependence on welfare, and families living on the poverty line (Petrovic, 2015, p.14-25) .

Many state and local governments force unauthorized immigrants to leave their communities therefore lose economically. These problems effect on policymakers reconsider their views to immigrants and immigration problems. (Rodríguez, Chishti, \&Nortman, 2007, p.8-47). Local and State policymakers should understand the interconnecting dynamics of changing migration flows and security challenges (Papademetriou, Doris, \& Eleanor, 2013, pg.15).

\section{Integration and Social Inclusion for Immigrants and Refugees}

Integration is an important indicator which includes five main gages, which are language abilities, socio-economic achievement, political participation, residential locale, and social interaction with host communities. These gages are important to understand about full integration of immigrants into the United States. Full integration into the United States communities takes more than one generation because the newcomers are learning English, interacting with members of the receiving society, and beginning to participate in the political process. (Jiménez, 2011, pg.5-7). Therefore, policymakers, governments, and agencies should take into account five main instruments of integration, when they create policy about immigrants.

The United States is often observed as a successful model for immigration integration. The United States invests in immigration at all levels of government, considering the education systems and social services at the state and local levels. Whichever terminology, of integration or assimilation, melting-pot, salad bowl, or mosaic is used, American history has been successful as a result of large-scale immigration. Integration takes place across immigrant groups and includes most pointers of social, economic, and cultural mobility, such as educational accomplishment, participation in the labor force, income, and job quality.

Generations of immigrants assess progress differently. First-generation immigrants have been employed at lower socioeconomic levels; however, second-generation immigrants improve substantially to their parents, regarding indicators such as, language proficiency, socioeconomic attainment, citizenship, political participation, housing integration, and social life (Fargues, Demetrios, Papademtriou, Giambattista, \& Madeleine, 2011, pg.8-9). For instance, second generations of immigrant teenagers from Latin America have higher degrees and more successful graduation records than the newcomers' generations (Meissner, Meyers, Papademetriou, \&Fix, 2006, pg.37). To be successfully integrated, newcomers should participate in decision-making and coalitions. These vehicles of integration can substitute for effective collaboration in order to meet the challenges of economic, cultural and social change. Therefore, government, non-government, and private partnership should be included in attracting individual immigrants to participate in the decision-making process. Resources should flow to integration-focused policy to create coalitions as well as building and training opportunities (Mudde, 2012, pg.10-21).

The immigration system should cover how to enforce immigration laws, how to process immigration benefits, how to encourage business innovation, and how to welcome immigrants to this nation. (Boushey, 2007, pg.3-8). Integration allows immigrants and refugees to achieve both economic independence and civic participation, depending on institutions and organizations.

A national integration and immigrant policy should seek to build relationships between government and civil society to achieve positive integration outcomes for newcomers and their families. Local levels of relationships between different kinds of organizations should be built to respond to the immigration challenges of social, economic, cultural, and political integration. Policymakers at the local and state levels have the resources to attempt such an integration programs. Also, elected representatives have a direct impact on refugees' and immigrants' education, transportation, workforce development or law enforcement. Integration depends on not only individual capital, friendship networks, and family resources, but also society's willingness to remove barriers to social and economic inclusion (Mudde, 2012, pg.27).

After all reviewing of literature about immigration, and integration of immigrants, there are several essential points, which are founded. The most important idea is that Immigration is a vital component of economic growth and competitiveness. Migrants closely linked in the United States economies. However, the influence of the economic crisis on immigration resulted in a complicated process, which is hard to interpret (Jiménez, 2011, pg.3-7). Immigration plays a serious role 
regarding complicated cultural, religious, security, economic, and political problems. (Mudde, 2012, p.7). The U.S. model of immigration faces a major problem, which is the economic climate. Immigrants' social and economic integration should link to their destination communities. Integration policy failed with anxiety about security the immigrants after $9 / 11$. The U.S. refugee resettlement systems also face some challenges. These challenges include insufficient coordination between the various government and nongovernmental entities (Fargues, Demetrios, Papademtriou, Giambattista, \& Madeleine, 2011, p.12).

\section{Recommendations and Conclusion}

The politics of immigration has played an important role in American political development. The conception of America as an immigrant nation, that should be open to racially, ethnically, linguistically, and culturally diverse populations, has been challenged by policymakers. While the numbers of immigrants are growing, integration is driven more than immigranttargeted policies (Jiménez, 2011, p.18-21). The politics of immigration in the United States includes different target groups, but immigration policy making will be necessary for solving immigration problems in the United States (Thangasamy, 2010, p.24-52). Governments should be open to learning lessons from immigrants' experiences and adopting innovative new ideas. Government works together public and private sectors to adapt programs consider strategies to bring immigrants new knowledge and ideas (Fourth Plenary Meeting of the Transatlantic Council on Migration, p.1). There is a vital demand for new and comprehensive thinking about involving immigrants in national policies. Therefore, the United States needs a new immigration policy and systems for integrating immigrants into its communities. Policymakers should have better information and knowledge to accomplish immigration and integrate immigrants properly (Somerville, Durana, \& Terrazas, 2008, p.1-24).

The immigrant community must lead the two-way interaction, which local communities should not only support, but also encourage training for immigrants and refugees. The host communities should also acquire the resources to better understand refugee and immigrant resettlement and cultural practices. Governments should improve the cultural integration of immigrants. Therefore, they should not only establish policies that allow different immigrant groups, but also protect the majority culture as well as the minority culture (Joppke, 2012, p.1-15). To be successful integration of newcomers with local communities must build strong economic, social, and cultural ties. The process of two- way interaction includes not only immigrants but also receiving countries (Meissner, Meyers, Papademetriou, \&Fix, 2006, p.70). Policymakers should regulate status of unauthorized immigrants, redesign electoral systems, develop and coordinate policies toward immigrants and immigration, enhance civic organizations that integrate immigrants into communities, figure out the implications of transnational legal statuses, incorporate immigrants and their children into schools, jobs, and neighborhoods, and prevent isolated, ideologically motivated youth (Hochschild \&Mollenkof, 2008, p.3-5).

Immigration policy should be set in response to domestic demands and take into account the safety of foreign countries. If the countries want to develop international policies, they have to consider the regions, which are an important element in making immigration policy (Terrazas, 2011, p.23). Policymakers should consider policy actions, invest budgets, and innovate program design, including expanding and innovating parent education and English language programs (Park, \& McHugh, 2014, p.16-18). To be successful, policy should consider how migrants work together regarding the multiple social, cultural, economic, and political interests. The most important governance priorities should be throughout the region, local, and state with accountability and transparency. Regional economic growth triggers the whole of countries which policymakers take into account when building physical and human-capital infrastructures to attract economy for both immigrants and citizens (Papademetriou, Doris, \& Eleanor, 2013, p.10-64). The United States should seek the ways of better understanding immigrants and encouraging their integration and participation in communities. If local governments maximize the benefits of immigration among newcomers and host communities, they solve problems of public education, health, and safety services of immigrants immediately and enhance efforts regarding successful linguistic, economic, and civic integration of new comers and their families.

However, federal civil rights provide these services and consider it a waste of public funds with too many communication barriers for effective services (McHugh, 2014, p.2-5). Integration of immigration is not only becoming complex but also costly.

Public policy on immigration in the United States needs four essential components, enforce both border and workplace, create a market- sensitive mechanism for legal immigration, be fair in addressing the problem of illegal immigration, integrate immigrants into communities, promote learning English (Westen, 2009, p.3-13). The best immigration policy 
should target not only seeking policy objectives and the outcomes with the evolution of immigration flows, such as demographic, economic, and geopolitical circumstances, but also register the social impact and cultural reactions of immigration. The heart of effective immigration systems is derived from flexibility, adaptability, and the capability to learn from domestic and international experiences, and efforts.

Policymakers of the United States invest in education workforce-training systems, develop public infrastructure, think about regulatory policies and social protection reforms, reduce barriers to employment and create incentives to work (Fargues, Demetrios, Papademtriou, Giambattista, \& Madeleine, 2011, p.18-20).

\section{References}

[1] Asch, Beth J. Emigration and Its Effects on the Sending Country.1994.

[2] http://www.rand.org/pubs/monograph_reports/MR244. Also available in print form. Santa Monica, CA: RAND Corporation.

[3] Brick, Kate,A. E.Challinor, and Marc R. Rosenblum.2011. Mexican and Central American Immigrants in the United States. Washington, DC: Migration Policy Institute.

[4] Boushey, H.2007. Social Inclusion for the United States. www.inclusionist.org. Department of Homeland Security (DHS), Office of Immigration Statistics. 2014. 2013 Yearbook of Immigration Statistics. Washington, DC: DHS Office of ImmigrationStatistics. Available Online.

[5] Demetrios G. Papademetriou and Annette Heuser, 2010. Immigrant Integration: Priorities for the Next Decade Council Statement from the Fourth Plenary Meeting of the Transatlantic Council on Migration.

[6] Fargues, Philippe, Demetrios G. Papademetriou, Giambattista Salinari, \& Madeleine Sumption. 2011. Shared Challenges and Opportunities for EU and US Immigration Policymakers. Florence and Washington, DC: European University Institute and Migration Policy Institute.

[7] Gold \&Rumbaut. 2009. The New Americans: Recent Immigration and American Society.

[8] Hamutal B. \& Martin S. 2011. Migration: Ensuring access, dignity, respect for diversity and Social inclusion. Georgetown University.

[9] Hirschman C. 2014. Immigration to the United States: Recent Trends and Future Prospects. Malays J Econ Studies; 51(1):69-85.

[10] Historical Trends in U.S. Immigration Policy. 2015. Retrieved from: http://www.migrationpolicy.org/programs/data-hub/us-immigration-trends\#history. Washington, DC: Immigration Policy Institute.

[11] Hochschild, Jennifer L, \& Mollenkof, J.2008. The Complexities of Immigration: Why Western Countries Struggle with Immigration Politics and Policies. Washington, DC: Migration Policy Institute.

[12] Jiménez, Tomás R. 2011. Immigrants in the United States: How Well Are They Integrating into Society? Washington, DC: Migration Policy Institute.

[13] Joppke, Christian. 2012. The Role of the State in Cultural Integration: Trends, Challenges, and Ways Ahead. Washington, DC: Migration Policy Institute.

[14] Kallick, David Dyssegaard. 2012. Immigrant Small Business Owners: A Significant and Growing Part of the Economy. New York, NY: Fiscal Policy Institute, June, p. 1. http://www.fiscalpolicy.org/immigrant-smallbusiness-owners-FPI-20120614.pdf Retrieved from: 14.04.2017

[15] Kallick, David Dyssegaard. 2015. Bringing Vitality to Main Street: How Immigrants Small Business Help Local Economies Grow, Fiscal Policy Institute and Americas Society/Council of the Americas, January, p.2 . $<$ <ttp://www.as-coa.org/articles/bringing-vitality-main-street-how-immigrant-small-businesses-help-localeconomies-grow>. Retrieved from: 04.04.2017

[16] McHugh, Margie. 2014. Immigrant Civic Integration and Service Access Initiatives: City-Sized Solutions for CitySized Needs. Washington, DC: Migration Policy Institute.

[17] Meissner Doris, Meyers Deborah W., Papademetriou Demetrios G., \& Fix Michael. 2006. Immigration and America's Future: A New Chapter. Washington, DC: Migration Policy Institute.

[18] Mudde, C. 2012. The Relationship between immigration and nativism in Europe and North America. Washington, DC: Migration Policy Institute.

[19] Office of Refugee Resettlement. 2015. Building the New American Community Newcomer Integration and Inclusion Experiences in Non-Traditional Gateway Cities. 
[20] OECD. 2017. Migration Policy. https://www.oecd.org/migration/OECD\%20Migration\%20Policy\%20Debates\%20Numero\%202.pdf Retrieved from: 25.04.2017.

[21] Papademetriou, Demetrios G., Doris Meissner, and Eleanor Sohnen. 2013. Thinking Regionally To Compete Globally: Leveraging Migration \& Human Capital in the U.S., Mexico, and Central America. Washington, DC: Migration Policy Institute.

[22] Park, Maki and Margie McHugh. 2014. Immigrant Parents and Early Childhood Programs: Addressing Barriers of Literacy, Culture, and Systems Knowledge. Washington, DC: Migration Policy Institute.

[23] Peri, Giovanni. 2006. Rethinking the Effects of Immigration on Wages: New Data and Analysis from 1990-2004. Washington, DC: Immigration Policy Center, American Immigration Law Foundation, p. 6.

[24] Petrovic, Milica. 2015. Mentoring in Europe and North America: Strategies for improving Immigrants' employment outcomes. Brussels: Migration Policy Institute Europe.

[25] Rodríguez, C., Chishti, M., Nortman, K. (2007). Testing the Limits: A Framework for Assessing The Legality of State and Local Immigration Measures. Washington, DC: Migration Policy Institute.

[26] Siavelis, P., \& Coates, D. (2009). Getting Immigration Right: What Every American Needs to Know. Washington, D.C.: Potomac Books, Inc.

[27] Somerville W. Durana J, and Terrazas A. 2008. Hometown Associations: An Untapped Resource for Immigrant Integration? Washington, DC: Migration Policy Institute.,

[28] Stephen Goss, et al., 2013. Effects of Unauthorized Immigration on the Actuarial Status of the Social Security Trust Funds. Actuarial Note no. 151 (Baltimore, MD: Office of the Chief Actuary, Social Security Administration, April), p. 3, <https://www.ssa.gov/oact/NOTES/pdf_notes/note151.pdf>.Retrieved from: 28.03.2017

[29] Thangasamy, A. (2010). State Policies for Undocumented Immigrants: Policy-Making and Outcomes in the U.S., 1998-2005. El Paso: LFB Scholarly Pub. LLC.

[30] Terrazas, Aaron. 2011. Migration and Development: Policy Perspectives from the United States. Washington, DC: Migration Policy Institute.

[31] The Effect of Immigration on the United States Economy. 2017. http://www.budgetmodel.wharton.upenn.edu/issues/2016/1/27/the-effects-of-immigration-on-the-united-stateseconomy. Retrieved from: 25.04.2017

[32] United States. Department of Homeland Security. Yearbook of Immigration Statistics: 2013.

[33] Washington, D.C.: U.S. Department of Homeland Security, Office of Immigration Statistics, 2014.

[34] Westen, Drew. 2009. Immigrating from Facts to Values: Political Rhetoric in the US Immigration Debate. Washington, DC: Migration Policy Institute. 